\title{
Peningkatan dan Aktivitas Enzim Asetilkolinesterase pada Nyamuk Aedes aegypti yang Diseleksi dengan Malation
}

\author{
DJ. GUNANDINI DAN P. B. WICAKSANA \\ Departemen Parasitologi dan Patologi, FKH-IPB \\ Jl. Agatis, Kampus IPB Darmaga, Bogor \\ (diterima Mei 2004, disetujui Agustus 2005)
}

\begin{abstract}
The Elevated and Activity of Acetilcholinesterase Enzyme on Aedes aegypti Selected by Malathion. The aim of this research was to study the effect of selection by malathion on the activity level of acetilcholinesterase enzyme on Aedes aegypti mosquitoes. Selection of Atdes atgypti larval by means of malathion have been conducted for 20 generations. During the selection process time has been inceased of the concentration applied and exposure. For generation 0-5 (F0-F5), a concentration of $25 \mu \mathrm{l} / 1(24 \mathrm{pPm})$ was used to expose the larvae to malathion for five minutes. In generation $6-10(\mathrm{~F} 6-\mathrm{F} 10)$ the concentration has increased to $50 \mu \mathrm{l} / 1$ (48 ppm); in F11-F15 the concentration used was $100 \mu \mathrm{l} / 1(96 \mathrm{ppm})$ whereas in F16-F20 $200 \mu \mathrm{l} / \mathrm{l}(192 \mathrm{ppm})$ was used. Mosquito generations that would be regarded as representative and reference groups were F0, F5, F10, F15 and F20. The $\mathrm{LC}_{9}$ of F0, F5, F10, F15 and F20 was 0,$025 ; 0,032 ; 0,042 ; 0,062$ and 0,071 $\mathrm{ppm}$ respectively. Increase $\mathrm{LT}_{40}$ values was also observed in Aedes aegypti selected by malathion. The $\mathrm{LT}_{50}$ of the F0, F5, F10, F15 and F20 generations was 7,9;11,3; 18; 30,6 and 33,1 minutes respectively. The low levels of malathion resistance could be conferred by the elevated of $\alpha$-esterase. The values of the $\alpha$-esterase in F0, F5, F10, F15 and F20 were 0,$155 ; 0,174 ; 0,203 ; 0,209$ and $0,215 \mu \mathrm{mol} / \mathrm{min} / \mathrm{mg}$ protein respectively. The accrilcholinesterase activities were also raised in F0, F5, F10, F15 and F20, the value of acetilcholinesterase activities were 20,$35 ; 20,26$; 23,$14 ; 23,18$ and $24,9 \%$.
\end{abstract}

KEY WORDS: Aedes aegypti, malathion, esterase.

\section{PENDAHULUAN}

Nyamuk Aedes aegypti yang menjadi vektor utama penyakit demam berdarah tersebar di seluruh wilayah Indonesia dan hidup di sekitar permukiman manusia terutama di daerah perkotaan. Nyamuk ini di alam dapat mencapai usia dua minggu cukup untuk membuat virus dengue menjadi infekrif (masa inkubasi ekstrinsik), sehingga nyamuk ini sangat efektif dalam penularan penyakit demam berdarah. Selain itu, sifat nyamuk yang sangat mudah terganggu pada waktu menghisap darah menyebabkan serangga ini scmakin potensial sebagai vektor karena kerap berpindah-pindah inang pada waktu menggigit.

Penyakit demam berdarah yang disebabkan oleh virus dengue hanya dapat ditularkan melalui perantaraan nyamuk 
sebagai vektor. Di Indonesia, penyakit ini pertama kali ditemukan di Jakarta dan Surabaya pada tahun 1968. Sejak itu penyakit demam berdarah terus mewabah dan meluas. Ditjen PPM dan PLP, Departemen Keschatan (2000) menyatakan bahwa pada tahun 2000 terdapat $223(73,6 \%)$ daerah dari 303 Daerah Tingkat II di seluruh propinsi di Indonesia telah terjangkit penyakit ini.

Pengendalian nyamuk Aedes aegypti menggunakan malation yang termasuk ke dalam insektisida golongan organofosfat telah dilakukan sejak tahun 1972 dalam rangka membatasi penyebaran penyakit demam berdarah di Indonesia. Bila dihitung sejak awal maka penggunaan insektisida malation di Indonesia telah berjalan lebih dari tiga dasawarsa. Negara tetangga kita, yakni Malaysia dan Singapura, telah melaporkan adanya kasus resistensi terhadap malation pada nyamuk, karena itu, bila tidak hati-hati dan tidak mengikuti tata cara penggunaan insektisida yang benar maka tidak mustahil bahwa di Indonesia juga terjadi masalah resistensi.

\section{TINJAUAN PUSTAKA}

Salah satu kerugian yang terjadi akibat penggunaan insektisida secara terus menerus adalah timbulnya galur serangga yang resisten. Dosis insektisida yang semula dapat digunakan untuk membunuh serangga menjadi tidak efektif lagi dalam pengendalian. Kejadian resistensi terus bertambah dan semakin meluas seiring dengan semakin meluas- nya penggunaan insektisida di seluruh dunia. Jumlah serangga dan tungau yang resisten terhadap insektisida pada akhir tahun 1980 sebanyak 428 spesies, dari jumlah ini $260(60,7 \%)$ jenis merupakan serangga hama pertanian dan 168 jenis $(39,3 \%)$ merupakan serangga yang berkepentingan dalam kesehatan manusia dan hewan (Georghiou and Mellon, 1983). Pada tahun 1984 jumlah serangga resisten meningkat menjadi 447 spesies (Metcalf, 1989).

Penggunaan malation dalam pengendalian penyakit demam berdarah terutama ditujukan untuk membunuh nyamuk dewasa. Di Indonesia, malation mulai digunakan sejak tahun 1972, diaplikasikan dengan menggunakan cara pengasapan (fogging). Malation untuk pertama kalinya dibuat di Jerman pada tahun 1934 oleh Schrader.

Malation pada serangga bekerja sebagai racun syaraf. Sistim syaraf pada serangga terdiri dari sel-sel syaraf atau neuron yang di dalam neuron terdapat organel-organel antara lain nukleus dan mitokhondria. Bagian neuron yang memanjang disebut akson. Rangsangan syaraf atau impuls merambat dari satu neuron ke neuron yang lain di sepanjang akson. Bagian akson yang bercabangcabang disebut dendrit, dan dendrit merupakan cabang neuron yang berfungsi sebagai penerima impuls. Ujung akson yang berada paling akhir bertemu dengan sel neuron lainnya untuk meneruskan impuls, di antara keduanya terdapat celah sinaptik. 
Asetilkolin (Ach) adalah suatu polipeptida yang mempunyai berat molekul 80.000 Dalton dan berfungsi sebagai neurotransmiter pada proses penghantaran impuls pada sistim syaraf serangga. Bila suatu transmisi impuls terjadi dan perintah telah diteruskan, kelebihan dari asetilkolin tersebut akan dihilangkan dari sinaps oleh suatu enzim yaitu asetilkolinesterase (AchE). Bila kelebihan asetilkolin tidak dihidrolisis oleh enzim asctilkolinesterase, maka dapat terjadi akumulasi asetilkolin sehingga pada serangga dapat terjadi gangguan transmisi impuls, gelisah, hipereksitabilitas, tremor, konvulsi, paralisis dan akhirnya kematian. Gugus karboksil yang dimiliki malation menyebabkan insektisida ini mudah terhidrolisis dalam tubuh mamalia. Malation bekerja dengan cata menghambat enzim asetikolinesterase sehingga enzim ini tidak dapat menghidrolisis asetilkolin.

Perkembangan sifat resisten mempunyai dua karakter yang dapat dibedakan, yaitu (1) kejadian resisten dimana secara de novo gen resisten telah ada sebagai suatu kesatuan genom yang dimiliki oleh serangga sebagai suatu individu. Peristiwa pertama dapat terjadi akibat dari kejadian jutaan tahun yang lalu tetapi terckspresi pada generasi yang sekarang meskipun demikian waktu terjadinya bukan merupakan suatu masalah yang penting. Pada populasi serangga, hal ini berarti adanya perubahan pada Deaxyribose Nucleic Acid (DNA) sehingga berkembang kearah resistensi. Pada kejadian demikian selain proses tesistensi bio-kimia dan fisiologi, juga melibatkan resistensi perilaku, dan (2) penyebaran mekanisme resistensi di dalam suatu populasi (Brattsten, 1992).

Small (1998) menjabarkan mekanisme resistensi ke dalam tiga kelompok, yaitu (1) resistensi kutikula, masuknya insektisida berkurang karena penebalan atau terjadinya perubahan komposisi kimia pada kutikula serangga; (2) resistensi metabolisme, terjadi karena perubahan kuantitas maupun kualitas enzim yang memetabolisme insektisida sebelum racun tersebut mencapai target kerjanya dan (3) menurunnya kepekaan titik tangkap insektisida, yang menyebabkan kegagalan molekul-molekul insektisida untuk berinteraksi.

Tiga kelompok enzim yang bertanggung jawab pada mekanisme resistensi secara biokimia adalah (1) Glutation S-tranfferase, yaitu cnzim yang mendetoksifikasi racun dari golongan insektisida organoklorin; (2) Esterase, enzim yang terlibat dalam resistensi terhadap golongan insektisida organofosfat, karbamat dan sedikit memberi pengaruh pada resistensi terhadap golongan piretroid, dan (3) monooksigenase, yang berpengaruh pada metabolisme golongan insektisida piretroid, organofosfat dan sedikit pada resistensi terhadap golongan karbamat (Hemingway and Ranson, 2000).

Kelompok insektisida yang termasuk golongan organofosfat mempunyai gugus ester dari asamfosfat. Insektisida yang mempunyai ikatan ester dapat di- 
hidrolisis oleh enzim esterase. Mekanisme inilah yang cenderung terjadi pada resistensi terhadap insektisida organofosfat. Resistensi dapat terjadi karena perubahan kuantitatif dan atau kualitatif pada esterase (karboksilesterase). Bila yang terjadi perubahan kuantitatif maka yang berperan adalah mekanisme sekuestrasi (pengikatan substrat oleh enzim), sedangkan bila yang terjadi perubahan kualitatif maka yang lebih berperan adalah kecepatan karboksilesterase dalam menghidrolisis insektisida menjadi lebih cepat dibandingkan dengan pada serangga yang normal (Small, 1998).

Meningkatnya aktivitas enzim dapat terjadi karena berbagai mekanisme kerja molekular. Salah satunya adalah amplifikasi dari gen yang mengkode enzim sehingga jumlah enzim menjadi lebih banyak. Jumlah enzim yamg berlebih dapat juga terjadi karena perubahan regulasi (dalam hal ini bertambahnya transkripsi) atau bertambah stabilnya messenger Ribo Nucleic Acid (mRNA). Terakhir adalah terjadinya satu atau lebih mutasi di dalam struktur gen sehingga kemampuan enzim dalam proses katalisis insektisida meningkat (Plapp and Wang, 1983).

Esterase adalah enzim hidrolase yang menguraikan ester dengan penambahan air menjadi alkohol dan asam. Dua esterase yang penting dalam metabolisme insektisida adalah karboksilesterase dan fosfatase. Karboksilesterase walaupun dihambat oleh insektisida organofosfat tetap dapat men- degradasi insektisida tersebut terutama bagi ester karboksilik dan fosforotioat (Matsumura, 1985).

Enzim esterase yang mampu mendetoksifikasi insektisida dari golongan organofosfat telah dipelajari pada berbagai spesies nyamuk, contohnya pada genus Culex, Anopbeles dan Aedes. Enzim esterase ini bekerja secara cepat dalam mengikat titik tangkapnya dan lambat dalam memulihkan kembali kedalam keadaan normal. Secara ringkasnya, enzim ini lebih cepat dalam mengikat toksin insektisida dibandingkan dengan memetabolisme insektisida tersebut. Dua lokus esterase yang umum pada genom yang terlibat dalam mekanisme resistensi adalah est $\alpha$ dan est $\beta$ yang keduanya dapat bekerjasama atau bekerja sendiri dalam menentukan sifat resisten terhadap insektisida organofosfat. Pada Culex quinquefasciatus umumnya peningkatan esterase secara fenotip melibatkan kedua enzim est $\alpha 2$ dan est $\beta 2$. Klasifikasi dari esterase ini didasarkan pada reaksi biokimia esterase terhadap $\alpha$ atau $\beta$-naftil asetat, pergerakan pada poliakrilamid gel dan sekuensing nukleotida (Hemingway and Ranson, 2000).

\section{BAHAN DAN METODE}

\section{Pengadaan dan Pemeliharaan Nya- muk A. aegypti}

Telur nyamuk $A$. aegypti diperoleh dari wilayah Cimanggu, Bogor. Dalam waktu beberapa hari (sekitar satu minggu) telur-telur yang telah diperoleh di- 
tetaskan di laboratorium. Larva yang telah menetas dipindahkan ke dalam nampan berukuran $30 \mathrm{~cm} \times 23 \mathrm{~cm} \times 4 \mathrm{~cm}$ yang berisi air $500 \mathrm{ml}$. Makanan larva adalah hati ayam rebus yang dihaluskan. Pemberian makan dilakukan secara ad libitum sekali sehari. Media air diganti setiap dua sampai tiga hari sekali. Setelah larva berkembang menjadi pupa, pupapupa tersebut segera dimasukkan ke dalam gelas plastik bervolume $200 \mathrm{ml}$ yang diisi air $3 / 4$ bagian. Gelas yang telah berisi pupa tersebut dimasukkan ke dalam kandang nyamuk dewasa yang berukuran $40 \mathrm{~cm} x$ $40 \mathrm{~cm} \times 40 \mathrm{~cm}$.

Nyamuk $A$, aegypti yang tclah menetas diberi makan air gula dengan konsentrasi 10\%. Nyamuk betina setiap tiga hari sekali diberi makan darah yang berasal dari hewan marmut.

\section{Pemaparan Larva $A$. aegypti dengan Insektisida Malation}

Larva $A$, Aegypti instar keempat dipaparkan dengan malation dalam konsentrasi dan waktu kontak tertentu, Pemaparan dilakukan mulai generasi pertama (F0) sampai generasi ke-20 (F20). Insektisida diperoleh dari Dinas Kesehatan Kotamadya Bogor dengan formulasi Malation $96 \mathrm{EC}$.
Konsentrasi malation yang mulamula digunakan untuk F0 adalah konsentrasi yang terendah, yaitu $25 \mu \mathrm{l} \mathrm{mala-}$ tion 96 EC dicampur dengan $25 \mu \mathrm{l}$ ethanol absolut (1:1) lalu dilarutkan dalam $1000 \mathrm{ml}$ (24 ppm) dan diaduk sampai rata di dalam nampan berukuran $30 \mathrm{~cm} \times 23 \mathrm{~cm} \times 4 \mathrm{~cm}$. Sebanyak 20 ekor larva $A$. aegypti instar keempat $\left(\mathrm{L}_{1 \mathrm{v}}\right)$ dimasukkan ke dalam larutan insektisida tersebut dan dibiarkan terpapar selama beberapa menit. Setelah dipaparkan, larva diambil dengan pipet dan dipindahkan ke dalam nampan yang berisi air jernih $500 \mathrm{ml}$, setelah 24 jam larva yang bertahan hidup dihitung, dan dipelihara sampai jumlah larva yang diperlukan cukup untuk dipaparkan kembali dengan insektisida. Konsentrasi dan lamanya waktu kontak dengan malation untuk tiap generasi tertera pada Tabel 1.

Jumlah larva nyamuk yang mati pada setiap generasi setelah kontak dengan malation dihitung dan dibandingkan. Setiap membutuhkan jumlah larva A. aegypti sebanyak 20 ekor. Jumlah ulangan untuk setiap generasi nyamuk tidak sama tergantung dari jumlah larva instar keempat yang tersedia. Penghitungan untuk mengetahui perbedaan besarnya kematian antar generasi

Tabel 1. Pemaparan insektisida malation pada generasi nyamuk Ae. aegypti Fo-F20

\begin{tabular}{lcc}
\hline \hline Generasi nyamuk & Konsentrasi malation & Waktu kontak \\
\hline F0-F5 & $25 \mu$ H $(24 \mathrm{ppm})$ & 5 menit \\
F6-F10 & $50 \mu \mathrm{H}(48 \mathrm{ppm})$ & 5 menit \\
F11-F15 & $100 \mu / /(96 \mathrm{ppm})$ & 10 menit \\
F16-F20 & $200 \mu \mathrm{hl}(192 \mathrm{ppm})$ & 10 menit \\
\hline
\end{tabular}


nyamuk setelah dipaparkan dengan insektisida dilakukan dengan analisis ragam (Anova) dan dilanjutkan dengan uji jarak berganda Duncan.

\section{Uji Lethal Consentration $\left(\mathrm{LC}_{\mathrm{s}_{0}}\right)$}

$\mathrm{Uji}_{\mathrm{L}} \mathrm{LC}_{50}$ dilakukan pada nyamuk A. aegypti generasi $\mathrm{F} 0, \mathrm{~F} 5, \mathrm{~F} 10, \mathrm{~F} 15$ dan F20. Untuk setiap konsentrasi dilakukan tiga kali ulangan. Setiap ulangan memerlukan 3 × 20 ekor larva $A$. aegypti instar keempat. Konsentrasi awal diperoleh dari percobaan pendahuluan pada generasi F0 agar dapat diperkirakan besarnya konsentrasi selanjutnya. Mulamula malation dengan konsentrasi yang telah ditentukan berdasarkan percobaan pendahuluan dilarutkan ke dalam $500 \mathrm{ml}$ air di dalam nampan yang berukuran 20 $\mathrm{cm} \times 15 \mathrm{~cm} \times 4 \mathrm{~cm}$. Setelah insektisida tercampur merata, ke-20 ekor larva $A$. aegypti instar ke empat dimasukkan ke dalam larutan tersebut, larva diberi pakan secukupnya. Setelah 24 jam, kematian larva dihitung dan dicatat. Penghitungan nilai $L_{50}$ dilakukan dengan analisis probit.

\section{Uji Lethal Time $\left(\mathrm{LT}_{50}\right)$}

$\mathrm{Uji}_{\mathrm{j}} \mathrm{LT}_{\mathrm{s},}$ dilakukan dengan menggunakan metode Wheaton bottle yang dibuat oleh Brogdon and Mac Allister (1998). Nyamuk A. aegypti yang digunakan adalah nyamuk yang berusia 3-4 hari dan belum pernah menghisap darah.

Ulangan dilakukan lima kali (lima botol) yang masing-masing botol berisi
20 ekor nyamuk $A$. aegypti betina, dan satu botol berisi 20 nyamuk betina tanpa dilapisi insektisida digunakan sebagai kontrol. Konsentrasi insektisida malation yang digunakan (berdasarkan percobaan pendahuluan dan kepekaan nyamuk) adalah $15 \mu \mathrm{g} /$ botol. Pengamatan dilakukan setiap beberapa menit sampai tercapai nilai $\mathrm{LT}_{\mathrm{si}}$.

Pada penelitian ini untuk generasi Ae. aegypti F0, F5 dan F10 pengamatan dilakukan setiap 2 menit, sedangkan untuk F15 dan F20 pengamatan dilakukan setiap 10 menit. Hal ini dilakukan karena pada generasi F0 sampai generasi F10 bila pengamatan dilakukan setiap 10 menit maka tidak ditemukan waktu kematian $50 \%$ nya. Jumlah kematian nyamuk pada setiap waktu pengamatan dicatat. Penghitungan $\mathrm{LT}_{\mathbf{s}_{0}}$ dilakukan dengan analisis probit.

\section{Uji Peningkatan dan Aktivitas Enzim Esterase}

Uji peningkatan enzim esterase dan aktivitasnya dilakukan menurut metode Hemingway (1990). Pembacaan hasil reaksi dilakukan dengan Elisa Reader pada panjang gelombang $405 \mathrm{~nm}$.

\section{HASIL DAN PEMBAHASAN}

\section{Hasil Uji LC $\mathrm{L}_{50}$}

Tabel 2 menunjukkan bahwa nyamuk $A$. aegypti yang terus menerus terseleksi dengan malation mulai toleran terhadap insektisida tersebut, sehingga daya bunuhnya juga semakin melemah 
dan konsentrasi yang digunakan juga semakin besar. Dalam penelitian ini nyamuk $A$. aegypti masih dalam status kerentanan berderajat toleran, masih jauh untuk mencapai tahap resisten.

\section{Hasil Uji LT}

Waktu kematian $50 \%$ pada nyamuk $A$. aegypti terseleksi malation semakin meningkat dengan semakin seringnya nyamuk terpapar oleh insektisida. $\mathrm{LT}_{\text {so }}$ pada generasi F0, F5, F10, F15 dan F20 berturut-turut adalah sebagai berikut: 7,$9 ; 11,3 ; 18,0 ; 30,6$ dan 33,1 menit (Tabel 3).

Rasio resistensi dalam waktu juga berubah menjadi 1,43 kali pada F5, 2,28 kali pada F10, 3,87 kali pada F15 dan 4,19 kali pada F20. Dengan demikian, pada nyamuk Ae. aegypti terseleksi malation menunjukkan kemampuan untuk bertahan sehingga waktu yang diperlukan untuk membunuh nyamuk menjadi lebih lama. Dalam keadaan ini nyamuk dikatakan mulai toleran terhadap malation.

Kenaikan rasio resistensi terhadap malation tidak diperoleh secara mendadak melainkan terjadi secara bertahap sedikit demi sedikit. Resistensi merupakan sifat yang diturunkan, jadi secara bertahap dari generasi ke generasi sifat ini akan semakin besar bila serangga terus menerus dipaparkan dengan insektisida.

\section{Hasil Uji Peningkatan Esterase}

Pada mekanisme resistensi terhadap insektisida organofosfat, kadang dapat ditemukan kenaikan satu atau lebih esterase. Bila terjadi peningkatan pada $\alpha$-esterase dan $\beta$-esterase, berarti kedua gen yang mengkode esterase ini berada pada lokasi yang sama (amplicon). Bila hanya salah satu saja esterase yang meningkat, maka dapat dipastikan bahwa gen yang mengkode enzim ini diamplifikasi tersendiri (Small, 1998).

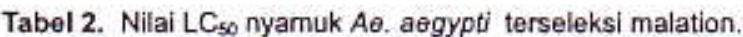

\begin{tabular}{lccc}
\hline \hline Generasi nyamuk & $\begin{array}{c}\text { LC } 5 \text { s } \\
\text { (ppm) }\end{array}$ & Persamaan Regresi & $\begin{array}{c}\text { Rasio Resistensi } \\
\text { (RR) }\end{array}$ \\
\hline F0 & 0,25 & $Y=-0,159+3,68 X$ & 1 \\
F5 & 0,32 & $Y=-0,578+3,71 X$ & 1,28 \\
F10 & 0,42 & $Y=-1,89+4,24 X$ & 1,68 \\
F15 & 0,62 & $Y=-1,84+3,81 X$ & 2,48 \\
F20 & 0,71 & $Y=-5,88+5,87 X$ & 2,84 \\
\hline
\end{tabular}

Tabel 3. Nilai $L T_{s_{0}}$ nyamuk $A \theta$. aegypti terseleksi malation.

\begin{tabular}{lrll}
\hline \hline Generasi nyamuk & $\begin{array}{c}\text { LC } \\
\text { (menit) }\end{array}$ & Persamaan Regresi & $\begin{array}{c}\text { Rasio Resistensi } \\
\text { (RR) }\end{array}$ \\
\hline F0 & 7,9 & $\mathrm{Y}=1,64+3,74 \mathrm{X}$ & 1 \\
F5 & 11,3 & $\mathrm{Y}=1,30+3,51 \mathrm{X}$ & 1,43 \\
F10 & 18 & $\mathrm{Y}=0,238+3,79 \mathrm{X}$ & 2,28 \\
F15 & 30,6 & $\mathrm{Y}=-4,63+6,48 \mathrm{X}$ & 3,87 \\
F20 & 33,1 & $\mathrm{Y}=-7,31+8,10 \mathrm{X}$ & 4,19 \\
\hline
\end{tabular}




\begin{tabular}{|c|c|c|c|}
\hline Generasi nyamuk & $N$ & $\begin{array}{c}\text { a-esterase } \\
(\text { Mean } \pm \text { SD })\end{array}$ & $\begin{array}{c}\text { B-esterase } \\
\text { (Mean + SD) }\end{array}$ \\
\hline Fo & 94 & $0,155 \pm 0,079$ & $0,166 \pm 0,034$ \\
\hline F5 & 94 & $0.174 \pm 0.053$ & $0,065 \pm 0,050$ \\
\hline F10 & 94 & $0.212 \pm 0.077$ & $0,095 \pm 0,062$ \\
\hline F15 & 94 & $0,209 \pm 0,034$ & $0,130 \pm 0,034$ \\
\hline $\mathrm{F} 2 \mathrm{O}$ & 34 & $0,183 \pm 0,036$ & $0,129 \pm 0,040$ \\
\hline
\end{tabular}

Tabel 5. Persentase Persenta se Aktivitas asetilkolinesterase nyamuk $A \theta$. aegypti terseleksi malation

\begin{tabular}{ccc}
\hline \hline Generasl nyamuk & N & $\begin{array}{c}\text { Persentase aktthas } \\
\text { aseblikolinesterase } \\
\text { (Mean } \pm \text { SD) }\end{array}$ \\
\hline F0 & 94 & $19,597 \pm 5,472$ \\
F5 & 94 & $24,21 \pm 47,08$ \\
F10 & 94 & $27,72 \pm 69,27$ \\
F20 & 94 & $19,68 \pm 15.59$ \\
\hline
\end{tabular}

Dari hasil uji peningkatan kedua macam enzim esterase ( $\alpha$-esterase dan $\beta$-esterase) terlihat bahwa secara kualitatif jumlah $\alpha$-esterase menunjukkan terjadinya peningkatan pada $A$. aegypti terseleksi malation meskipun pada generasi F20 terjadi penurunan nilai (Tabel 4). $\mathrm{Hal}$ ini kemungkinan dapat dikaitkan dengan terjadinya peningkatan angka kematian larva generasi F20 pada waktu seleksi dengan malation dibandingkan dengan kematian larva nyamuk generasi F5, F10 dan F15.

Nilai $\beta$-esterase pada nyamuk $A$. aegypti yang diseleksi malation dalam penelitian ini, secara kualitatif tidak menunjukkan adanya korelasi dengan peningkatan daya tahan nyamuk terhadap inscktisida. Dapat disimpulkan bahwa jenis enzim $\beta$-esterase tidak berperan dalam toleransi $A$. aegypti yang dipaparkan malation sampai 20 generasi. Menurut
Small (1998), bila terjadi keadaan demi kian berarti kedua gen yang mengkode kedua jenis esterase ini tidak berada pada lokasi yang sama. Kemungkinan yang lain adalah peningkatan rasio resistensi yang sedikit, yaitu 2,84 untuk $\mathrm{LC}_{\mathrm{si}}$ dan 4,19 untuk $\operatorname{LT}_{5 n}$ tidak cukup untuk menggertak gen yang mengkode enzim $\beta$-esterase.

\section{Hasil Uji Aktivitas Esterase}

Pada uji aktivitas asetilkolinesterase terlihat bahwa nyamuk $A$. aegypti yang diseleksi dengan malation mempunyai nilai rata-rata aktivitas sebagai berikut: generasi F0 $(18,597 \%)$, F5 $(24,21 \%)$, F10 $(27,72 \%)$, F15 $(19,68)$ dan F20 $(36,30 \%)$ (Tabel 5). Aktivitas asetilkolinesterase terlihat semakin meningkat pada nyamuk yang diseleksi dengan malation meskipun pada generasi F15 aktivitas terlihat menurun. Nilai aktivitas asctilkolinesterase yang tertinggi dimiliki olch generasi F20. Hemingway 
(1990) menyatakan bahwa bila nilai aktivitas asetilkolinesterase lebih dari $30 \%$, maka dapat dikatakan bahwa nyamuk tersebut termasuk dalam kategori resisten. Dari uji peningkatan aktivitas enzim asetilkolinesterasc ini dapat dipastikan bahwa pada generasi F20 nyamuk $A$. aegypti terseleksi malation sangat baik.

Mekanisme yang terjadi di dalam proses resistensi ini adalah terjadinya peningkatan kcgiatan dan fungsi enzim asetilkolinesterase sehingga enzim ini masih mampu menguraikan asetilkolin menjadi kolin dan asam asetat meskipun gempuran insektisida malation terus menerus terjadi. Dengan berjalannya fungsi enzim asetilkolinesterase ini maka impuls yang masuk pada sistim saraf serangga dapat diteruskan secara normal.

\section{KESIMPULAN}

Nyamuk A. aeg)pti yang discleksi dengan malation menunjukkan peningkatan daya tahan terhadap insektisida terbukti dengan meningkatnya nilai $\mathrm{LC}_{50}$ dan $\mathrm{LT}_{50}$. Peningkatan daya tahan terhadap malation disebabkan oleh me- kanisme biokimia yaitu adanya peningkatan enzim esterase dan juga peningkatan aktivitas enzim tersebut.

\section{DAFTAR PUSTAKA}

Brattsten, L.B. 1992. Potential Role of Plant Allelochemicals in The Development of Insecticide Resistanc. Rutgers University, New Jersey. p. 313-348.

Brogdon, W.G. and J.C. Mac Allister. 1998. Simplification of Adult Mosquito Bioassays Through use of Timemortality Determinations in Glass Bottle. J. Am. Mosq. Contr. Assoc. 11:416-418.

Hemingway, J. 1990. A Practical Field and Laboratory Manual for The Mechanistic Detection of Insecticide Resistance in Insects. Dept. of Med. Parasitol, London School of Hygienc and Tropical Med. p. 2540.

Hemingway J. and Ranson. 2000. Insecticide Resistance in Insect Vectors of Human Diseasc. Ann Rev. Entomol. 45:371-391

Matsumura, F. 1985. Toxicology of Insecticides. Plenum Press, New York. p. 65-264.

Metcalf, R.L. 1989. Insect Resistance to Insecticide. Pesticide Science. 26:333-358.

Plapp, FW. Jr. and T.C. Wang. 1983. Genetic Origins of Insecticide Resistance. In Pest Resistance to Pesticides. Bab 2. G.P. Georghiou, T. Saito. Editor, Plenum Press, New York. p. 47-70.

Small, G. 1998. Generical Background of Insecticide Resistance. In Molecular Entomology Workshop. Universitas Gajah Mada. 